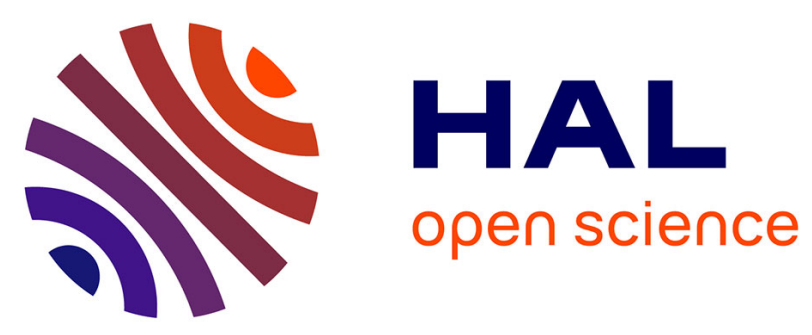

\title{
Amoxicillin crystalluria is associated with acute kidney injury in patients treated for acute infective endocarditis
}

Matthieu Jamme, Leopold Oliver, Julien Ternacle, Raphael Lepeule, Amina

Moussafeur, Jean-Philippe Haymann, Sovannarith San, Antonio Fiore, Nicolas

Mongardon, Michel Daudon, et al.

\section{To cite this version:}

Matthieu Jamme, Leopold Oliver, Julien Ternacle, Raphael Lepeule, Amina Moussafeur, et al.. Amoxicillin crystalluria is associated with acute kidney injury in patients treated for acute infective endocarditis. Nephrology Dialysis Transplantation, 2021, 10.1093/ndt/gfab074 . hal-03199048

\section{HAL Id: hal-03199048 \\ https://hal.sorbonne-universite.fr/hal-03199048}

Submitted on 15 Apr 2021

HAL is a multi-disciplinary open access archive for the deposit and dissemination of scientific research documents, whether they are published or not. The documents may come from teaching and research institutions in France or abroad, or from public or private research centers.
L'archive ouverte pluridisciplinaire HAL, est destinée au dépôt et à la diffusion de documents scientifiques de niveau recherche, publiés ou non, émanant des établissements d'enseignement et de recherche français ou étrangers, des laboratoires publics ou privés. 


\title{
Amoxicillin crystalluria is associated with acute kidney injury in patients treated for acute infective endocarditis
}

\author{
Matthieu Jamme ${ }^{1,2}$, Leopold Oliver ${ }^{3}$, Julien Ternacle ${ }^{3}$, Raphael Lepeule ${ }^{4}$, Amina \\ Moussafeur ${ }^{3}$, Jean-Philippe Haymann ${ }^{5,6}$, Sovannarith San ${ }^{3}$, Antonio Fiore ${ }^{7}$, Nicolas \\ Mongardon ${ }^{8}$, Michel Daudon ${ }^{5,6}$, Pascal Lim³, and Emmanuel Letavernier ${ }^{5,6}$
}

${ }^{1}$ Urgence Néphrologique et Transplantation Rénale, Hôpital Tenon, APHP, Paris, France

2INSERM U1018, Centre de recherche en épidémiologie et santé des populations (CESP), Equipe «Epidemiologie clinique », Université Paris Saclay, 16 avenue Paul Vaillant Couturier, 94800, Villejuif, France

3Unité SOS Endocardite, Service de Cardiologie, Hôpital Henri Mondor, APHP, Créteil, France

${ }^{4}$ Unité SOS Endocardite, Equipe mobile d'infectiologie, Hôpital Henri Mondor, APHP, Créteil, France

${ }^{5}$ Explorations fonctionnelles rénales, Hôpital Tenon, APHP, Paris, France

6Sorbonne Université, INSERM, UMR_S 1155, F-75020, Paris, France

7Unité SOS Endocardite, Service de Chirurgie cardiaque, Hôpital Henri Mondor, APHP, Créteil, France

${ }^{8}$ Unité SOS Endocardite, Anesthésie et Réanimation chirurgicale, Hôpital Henri Mondor, APHP, Créteil, France

Correspondence to: Matthieu Jamme; E-mail: matthieu.jamme@ght-yvelinesnord.fr 
Acute kidney injury (AKI) is a common complication of infective endocarditis (IE) with a reported prevalence of 30-50\%1,2. Antibiotic-associated crystals (AAC) nephropathy has been increasingly described as a cause of severe AKI secondary to antibiotic use ${ }^{3,4}$. Amoxicillin crystals are frequently observed but sulfamethoxazole, sulfadiazine, ceftriaxone and other antibiotics may form AAC in urine ${ }^{5}$. However, the prevalence of AAC in the urine of IE patients is unknown. Moreover, the impact of crystals on the renal function is unknown and always retrospectively described after exclusion of differential diagnosis ${ }^{3,4}$.

We aimed at (i) assess the prevalence and type of AAC in the urine of patients treated for suspected IE, (ii) identify factors associated with AAC and (iii) assess renal prognosis of AAC-positive patients.

We performed crystalluria study in adults patients admitted for suspicion of IE between 2017, June, $1^{\text {st }}$ and 2018, June, $1^{\text {st }}$. All crystalluria studies were realized in fresh morning urine samples collected, transferred and analyzed within 4 hours. 
Crystalluria examinations were performed without knowledge of the clinical status and biological results of the patients. Crystalluria was considered as positive if antibiotic crystals were observed in urine.

Primary outcome was the occurrence of urine AAC. Secondary outcome was the occurrence of AKI stage $\geq 2$ according to the KDIGO classification.

To identify risk factors of $A A C$, because several crystalluria analyses were sometimes performed in a same patient, we used a mixed multivariate logistic regression. To handle with this competing risk setting and time-dependent covariates, we used a Cox time-dependent cause specific model ${ }^{6}$. Multivariate model was built using all variables with a $P$ value lower than 0.20 in univariate analysis and then a stepwise backward selection was applied to select final variables. All statistical tests were two-sided using a type I error of 0.05 . This study has been approved by the ethics committee of the French Intensive Care Society (ref. CE SRLF, \#24-01).

Sixty-five crystalluria studies were performed in 34 patients with a median of 2 [1-2] samples per patient. Most of patients were men (71\%) and the median age was 70 [62-77] years. Baseline characteristics are shown in Supplemental Table 1.

First-line antibiotics were amoxicillin (88\%), gentamycin (82\%) and cefazolin (29\%). After adaptation to the pathogen, second-line antibiotics were amoxicillin $(60 \%)$, ceftriaxone (20\%), vancomycin (20\%) and rifampicin (20\%). Twenty-one (62\%) patients underwent surgery within a median time of 3 [2-8] days. Supplemental Table 2 reports treatments and events that occurred during hospitalization.

Crystalluria studies were realized within a median time of 3 [2-5] days after diagnosis. AAC was observed in 18 (28 \%) urinary samples from 14/34 (41\%) patients. All AAC identified were amoxicillin crystals (Figure 1). When positive, the median number of crystals was $8[3-18] / \mathrm{mm}^{3}$ and a microscopic hematuria was associated in 13/18 (72 $\%)$ of AAC cases. We identified 6 other positive crystalluria with uric acid $(n=2)$ or calcium oxalate crystals $(n=4): 4 / 47(8.5 \%)$ in the No AAC group and 2/18 $(11.1 \%)$ in the AAC group. Median serum creatinine level at the time of crystalluria was 99 [65- 
202] $\mu \mathrm{mol} / \mathrm{L}$. Multivariate logistic mixed effect analysis identified blood amoxicillin concentration $(\mathrm{OR}=1.03[1.01-1.05]$ per increase of $1 \mathrm{mg} / \mathrm{L})$, urine $\mathrm{pH}(\mathrm{OR}=0.78$ [0.62-0.97] per increase of 0,1 unit) and a trend was observed with urinary specific gravity (OR for $=1.25[0.80-2.73]$ per increase of 10 unit, $p=0.10)$ as risk factors of AAC (Supplemental Table 3).

AKI occurred in $16(47 \%)$ patients. The median time from admission to AKI was 5 [37] days. Multivariate Cox cause specific time-dependent analysis identified AAC (CSH $=7.44[1.83-30.25])$, septic shock at admission $(\mathrm{CSH}=13.29$ [2.25-78.60]) and use of vancomycin in first-line therapy $(\mathrm{CSH}=5.49[1.07-28.22])$ as risk factors of $\mathrm{AKI}$ occurrence (Table 1).

This study is the first to assess the prevalence and prognosis of AAC in a context of IE by repeated analysis of crystalluria.

In 2020, Garnier et al. identified, among 358 patients treated with high daily dose of amoxicillin, $73(20 \%)$ patients with AKI. AKI seemed related to antibiotic-induced crystal nephropathy in 16 patients. However, crystalluria study was performed 4.5 days after the onset of AKI and was positive in only 2 patients ${ }^{4}$.

In the present work, we highlight that high blood concentration of amoxicillin, low urinary $\mathrm{pH}$ and urine density are risk factors for amoxicillin crystal formation in urine. Crystals may form in urine when antibiotics are in a supersaturation state, depending on antibiotic concentration in urine and $\mathrm{pH}^{3,7}$.

Finally, we identify that AKI is a common complication of IE, and the presence of AAC in urine is an independent risk factor associated with the occurrence of renal dysfunction. Our prevalence of $A K I$ is quite similar to those already reported after $\mathrm{IE}^{8,9}$. In addition to amoxicillin crystals, we identified two other independent risk factors of AKI: use of vancomycin, a potentially nephrotoxic drug, and septic shock at admission ${ }^{10,11}$. 
Our study has strengths. First, we used polarized microscopy to detect crystals. Second, we prospectively analyzed the patients admitted in our center, not only patients with renal failure, to not overestimate the consequences of AAC. Third, because of the dynamic process of crystal formation, we collected several urine samples per patient to not underestimate the prevalence of AAC. Fourth, our biostatistical model is the most appropriate to handle with concurrent risk context and time-dependent covariate.

However our study has also major limitations. First, the small number of patients limits the power of statistical tests. Second, we could not apply a standardized chronological protocol of urine collection because crystalluria was not available during weekend and night. Third, no renal biopsy was performed in patients with AKI.

In conclusion, amoxicillin crystals are frequent in patients treated with high dose of amoxicillin for suspected IE, and their presence in urine predicts AKI. Our results suggest that repeated crystalluria analyses should be performed in patients receiving high doses of amoxicillin. An increase in urine output, urine alkalinization and a decrease in amoxicillin dose or a switch to other antibiotics may prevent AKI in these patients, deserving further studies.

\section{AUTHORS' CONTRIBUTIONS}

MJ designed the study, collected the data, performed the statistical analysis and drafted the manuscript. EL designed the study, performed crystalluria and drafted the manuscript. LO designed the study, collected the data and drafted the manuscript. JT, $\mathrm{RL}, \mathrm{AM}, \mathrm{JPH}, \mathrm{SS}, \mathrm{AF}, \mathrm{NM}, \mathrm{MD}$ and $\mathrm{PL}$ collected the data, contributed to data interpretation and analysis, and revised the manuscript for important intellectual content. 
None declared. This work was presented at the fourth congress of the French society of nephrology - dialysis - transplantation (SFNDT), 1-4 October 2019, Nancy, France and at the congress "Réanimation 2020", 5-7 February 2020, Paris, France.

\section{FUNDING}

This research did not receive any specific grant from funding agencies in the public, commercial, or not-for-profit sectors.

\section{REFERENCES}

1. Majumdar A, Chowdhary S, Ferreira MAS, et al. Renal pathological findings in infective endocarditis. Nephrol Dial Transplant 2000;15(11):1782-7.

2. Tamura K, Arai H, Yoshizaki T. Long-Term Outcome of Active Infective Endocarditis with Renal Insufficiency in Cardiac Surgery. Annals of Thoracic and Cardiovascular Surgery 2012;18(3):216-21.

3. Vodovar D, Thomas L, Mongardon N, et al. Dramatic Increase of AmoxicillinInduced Crystal Nephropathy Found in a Cohort Study of French Pharmacovigilance Centers. Antimicrob Agents Chemother 2018;62(3).

4. Garnier A-S, Dellamaggiore J, Brilland B, et al. High Incidence of AmoxicillinInduced Crystal Nephropathy in Patients Receiving High Dose of Intravenous Amoxicillin. Journal of Clinical Medicine 2020;9(7):2022.

5. Daudon M, Frochot V, Bazin D, Jungers P. Drug-Induced Kidney Stones and Crystalline Nephropathy: Pathophysiology, Prevention and Treatment. Drugs 2018;78(2):163-201.

6. Latouche A, Porcher R, Chevret S. A note on including time-dependent covariate in regression model for competing risks data. Biom J 2005;47(6):80714.

7. Sjovall J, Westerlund D, Alvan G. Renal excretion of intravenously infused amoxycillin and ampicillin. British Journal of Clinical Pharmacology 1985;19(2):191-201. 
8. Legrand M, Pirracchio R, Rosa A, et al. Incidence, risk factors and prediction of post-operative acute kidney injury following cardiac surgery for active infective endocarditis: an observational study. Crit Care 2013;17(5):R220.

9. Gagneux-Brunon A, Pouvaret A, Maillard N, et al. Acute kidney injury in infective endocarditis: A retrospective analysis. Med Mal Infect 2019;49(7):527-33.

10. Luque $\mathrm{Y}$, Louis $\mathrm{K}$, Jouanneau $\mathrm{C}$, et al. Vancomycin-Associated Cast Nephropathy. J Am Soc Nephrol 2017;28(6):1723-8.

11. Hoste EAJ, Bagshaw SM, Bellomo R, et al. Epidemiology of acute kidney injury in critically ill patients: the multinational AKI-EPI study. Intensive Care Med 2015;41(8):1411-23.

\section{TABLES}

$\underline{\text { Table 1. Time-dependent survival competing risk analysis of AKI }}$

\begin{tabular}{lcccccc}
\hline & \multicolumn{3}{c}{ Univariate Analysis } & \multicolumn{2}{c}{ Multivariate Analysis } \\
\hline & $\mathrm{CSH}$ & $95 \% \mathrm{Cl}$ & $P$ & $\mathrm{CSH}$ & $95 \% \mathrm{Cl}$ & $P$ \\
\hline Age $>$ 70 years & 0.75 & $0.26-2.17$ & 0.59 & & & \\
Male gender & 0.85 & $0.28-2.53$ & 0.76 & & \\
BMI $\left(+1 \mathrm{~kg} / \mathrm{m}^{2}\right)$ & 0.98 & $0.87-1.10$ & 0.72 & & \\
History of valvulopathy & 1.10 & $0.24-4.93$ & 0.90 & & \\
History of arterial hypertension & 0.67 & $0.23-1.93$ & 0.46 & & \\
History of mellitus diabetes & 0.62 & $0.14-2.75$ & 0.52 & & & \\
History of CKD & 0.57 & $0.10-4.36$ & 0.58 & & & \\
History of solid cancer & 0.72 & $0.16-3.34$ & 0.70 & & & \\
Septic shock at admission & & $1.59-$ & & & $2.25-$ & \multirow{2}{*}{0.004} \\
& 8.94 & 50.17 & 0.01 & 13.29 & 78.60 & \\
Congestive signs at admission & 0.38 & $0.10-1.66$ & 0.19 & & & \\
Fever & 1.26 & $0.35-4.54$ & 0.72 & & & \\
Native valve IE & 1.25 & $0.44-3.57$ & 0.68 & & &
\end{tabular}




\begin{tabular}{|c|c|c|c|c|c|c|}
\hline Positive documentation & 0.96 & $0.32-2.87$ & 0.94 & & & \\
\hline Staphylococcus. aureus & 1.34 & $\begin{array}{l}0.17- \\
10.33\end{array}$ & 0.78 & & & \\
\hline Streptococcus group & 2.93 & $0.97-8.88$ & 0.05 & & & \\
\hline Definite IE & 1.16 & $0.36-3.70$ & 0.80 & & & \\
\hline Possible IE & 1.13 & $0.25-5.05$ & 0.87 & & & \\
\hline WBC at admission $(+1 G / L)$ & 1.01 & $0.92-1.11$ & 0.86 & & & \\
\hline $\begin{array}{l}\text { Hemoglobin at admission } \\
(+1 \mathrm{~g} / \mathrm{dL})\end{array}$ & 0.92 & $0.68-1.25$ & 0.59 & & & \\
\hline $\begin{array}{l}\text { Platelets at admission } \\
(+10 \mathrm{G} / \mathrm{L})\end{array}$ & 1.02 & $0.95-1.10$ & 0.55 & & & \\
\hline $\mathrm{SCr}$ at admission $(+10 \mu \mathrm{mol} / \mathrm{L})$ & 0.96 & $0.80-1.15$ & 0.61 & & & \\
\hline AST at admission $(+10 \mathrm{UI} / \mathrm{L})$ & 1.18 & $1.07-1.32$ & $\begin{array}{c}0.00 \\
1\end{array}$ & & & \\
\hline ALT at admission (+10UI/L) & 1.14 & $1.04-1.24$ & $\begin{array}{c}0.00 \\
2\end{array}$ & & & \\
\hline $\begin{array}{l}1^{\text {st }} \text { line Amoxicillin }(+1 \mathrm{~g} \text { per } \\
\text { day) }\end{array}$ & 0.98 & $0.78-1.24$ & 0.89 & & & \\
\hline $1^{\text {st }}$ line Gentamycin & 0.63 & $0.14-2.79$ & 0.54 & & & \\
\hline $1^{\text {st }}$ line Vancomycin & 6.31 & $\begin{array}{l}1.72- \\
23.17\end{array}$ & $\begin{array}{c}0.00 \\
5\end{array}$ & 5.49 & $\begin{array}{l}1.07- \\
28.22\end{array}$ & 0.04 \\
\hline Positive AAC* & 3.38 & $\begin{array}{l}1.05- \\
10.97\end{array}$ & 0.04 & 7.44 & $\begin{array}{l}1.83- \\
30.25\end{array}$ & 0.005 \\
\hline Surgery* & 2.21 & $0.79-6.14$ & 0.12 & & & \\
\hline \multicolumn{7}{|c|}{$\begin{array}{l}\text { CSH, cause-specific hazard; } \mathrm{Cl} \text {, confidence interval; } \mathrm{BMI} \text {, body mass index; CKD, } \\
\text { chronic kidney disease; IE, infective endocarditis; WBC, white blood cells; } \mathrm{SCr} \text {, serum } \\
\text { creatinine; AAC, antibiotic associated crystals in urine; AST, aspartate } \\
\text { aminotransferase; ALT, alanine aminotransferase }\end{array}$} \\
\hline \multicolumn{7}{|c|}{$\begin{array}{l}\text { Initial multivariate model before stepwise variable selection included following } \\
\text { covariates: Septic shock at admission, Streptococcus group, SCr at admission, 1st } \\
\text { line Vancomycin, AST and ALT at admission, Positive AAC and surgery }\end{array}$} \\
\hline These variables had been an & yzed as & ime-depe & dent c & variates & & \\
\hline
\end{tabular}




\section{SUPPLEMENTAL MATERIALS}

Supplemental Table 1. Baseline characteristics

Supplemental Table 2. Treatment and evolution during hospitalization

Supplemental Table 3. Comparison according to occurrence of AAC in urine 
